\title{
FUNGSI RESES ANGGOTA DPRD DALAM MENGARTIKULASIKAN ASPIRASI MASYARAKAT KABUPATEN BANDUNG
}

\author{
Dewi Kurniasih $^{1}$ dan Yudi Rusfiana ${ }^{2}$ \\ ${ }^{1}$ Dosen Program Studi Ilmu Pemerintahan FISIP Unikom, \\ dewi.kurniasih@email.unikom.ac.id \\ ${ }^{2}$ Dosen Institut Pemerintahan Dalam Negeri, rusfianayoudhy@ gmail.com
}

\begin{abstract}
Abstrak
Demokrasi menjamin rakyat dapat mengemukakan aspirasinya. Namun terkadang media penyampaian aspirasi ini masih terbatas. DPRD sebagai lembaga perwakilan di daerah dituntut menjalankan fungsi mengartikulasikan aspirasi rakyat dalam kegiatan yang disebut reses. Metode yang digunakan dalam penelitian ini adalah metode deskriptif. Teknik pengumpulan datanya dilakukan melalui observasi langsung, wawancara dan Focus of Group Discussion. Analisa data dilakukan secara kualitatif. Hasil penelitian menunjukkan bahwa anggota DPRD Kabupaten Bandung sudah melaksanakan fungsi reses dengan baik sesuai jadwal yang telah ditentukan di daerah pemilihannya masing-masing. Masyarakat mengikuti kegiatan reses secara antusias ditengah pandemi Covid-19 dengan tetap menjaga protokol kesehatan secara ketat. Tentu tujuan masyarakat hadir dalam kegiatan reses tersebut cukup beragam. Tersirat sebuah harapan bahwa aspirasi mereka dapat ditampung oleh anggota DPRD dan kemudian disampaikan kepada pihak yang berkepentingan membuat kebijakan. Sehingga kegiatan reses ini tidak hanya bersifat politis saja mengingat anggota DPRD bertemu konstituennya, tetapi lebih kepada bagaimana jarring aspirasi dapat diartikulasikan.
\end{abstract}

Kata Kunci : Reses, Artikulasi, Aspirasi, Anggota, DPRD

\begin{abstract}
Democracy ensures that the people can express their aspirations. However, sometimes the media for conveying these aspirations is still limited. DPRD as a representative institution in the region is required to carry out the function of articulating the aspirations of the people in an activity called a recess. The method used in this research is descriptive method. The data collection technique is done through direct observation, interviews and Focus of Group Discussion. Data analysis was carried out qualitatively. The results showed that members of the Bandung Regency DPRD had carried out the recess function well according to a predetermined schedule in their respective constituencies. The community participated in the recess activities enthusiastically amid the Covid-19 pandemic
\end{abstract}


while maintaining strict health protocols. Of course, the purpose of the community attending the recess activity is quite diverse. There is an implicit hope that their aspirations can be accommodated by DPRD members and then conveyed to interested parties in making policies. So that this recess activity is not only political, considering that DPRD members meet their constituents, but rather how the net of aspirations can be articulated.

Keywords: Recess, Articulation, Aspiration, Member, DPRD.

\section{PENDAHULUAN}

Dewan Perwakilan Rakyat Daerah yang selanjutnya disingkat DPRD adalah lembaga perwakilan rakyat daerah yang berkedudukan sebagai unsur penyelenggara Pemerintahan Daerah. Selanjutnya penyelenggara Pemerintahan Daerah khususnya di kabupaten/kota terdiri atas kepala daerah dan DPRD dibantu oleh Perangkat Daerah. (UNDANG-UNDANG REPUBLIK INDONESIA NOMOR 23 TAHUN 2014 TENTANG PEMERINTAHAN DAERAH, 2014).

Anggota DPRD merupakan kepanjangan tangan rakyat. Sebagaimana termaktub dalam Undang-Undang Nomor 17 Tahun 2014 tentang MPR, DPR, DPRD dan DPD (MD3) menjelaskan bahwa "DPRD kabupaten/kota merupakan lembaga perwakilan rakyat daerah yang berkedudukan sebagai unsur penyelenggara pemerintah daerah kabupaten/kota. Anggota dari DPRD kabupaten/kota terdiri dari perwakilan partai politik yang merupakan peserta dari pemilihan umum yang dipilih oleh rakyat” (Rizka Azzahri, Seno Andri, \& Adianto, 2021).

Kewajiban anggota DPRD salah satunya adalah menyerap, menghimpun, menampung dan menindaklanjuti aspirasi masyarakat. Lebih lanjut kewajiban yang dimiliki anggota DPRD baik Kabupaten/Kota diantaranya adalah: (1) Mampu menyerap dan juga menghimpun setiap aspirasi dari aspirasi konstituen dengan melaksanakan kunjungan kerja secara berkala. Yang dimaksud dengan "kunjungan kerja secara berkala" adalah kewajiban anggota DPRD kabupaten/kota untuk bertemu dengan konstituennya secara rutin pada setiap masa reses, yang hasil pertemuannya dengan konstituen dilaporkan secara tertulis kepada partai politik melalui fraksinya di DPRD kabupaten/kota. Pemberian pertanggungjawaban secara 
moral dan politis disampaikan pada setiap masa reses kepada pemilih di daerah pemilihannya. (Pemerintah Republik Indonesia, 2014). (2) Anggota DPRD dapat menampung serta melakukan tindak lanjut dari aspirasi maupun pengaduan yang disampaikan masyarakat dan (3) Anggota DPRD juga dapat mempertanggungjawabkan setiap tugas baik moral maupun politis kepada konstituen terutama di daerah pemilihannya.

Bentuk dari proses penyampaian aspirasi yang diberikan oleh masyarakat kepada DPRD diantaranya melalui kegiatan reses anggota dewan. Reses sendiri sebagaimana disampaikan dalam undang-undang menjadi salah satu kewajiban yang harus dilaksanakan sebagai anggota DPRD yaitu menyerap serta menghimpun setiap aspirasi dari masyarakat melalui kunjungan kerja yang pelaksanaannya dilakukan secara berkala. Reses sebagai salah satu penyaluran aspirasi vertikal ke atas dari rakyat kepada pemerintah, dapat dilakukan melalui kunjungan DPRD ke daerah pilihan (dapil) kepada konstituennya, maupun melalui hasil musyawarah rencana pembangunan (Musrenbang), bisa juga melalui Kepada Daerah Setempat (Bupati) ataupun DPC/DPD Partai (Hendriyanto, 2020).

Berdasarkan Peraturan Bupati Bandung Nomor 42 Tahun 2020 tentang Petunjuk Teknis Pelaksanaan Kegiatan Reses Pimpinan dan Anggota DPRD Kabupaten Bandung dinyatakan bahwa "Reses adalah manifestasi kewajiban Pimpinan DPRD dan Anggota DPRD untuk melakukan komunikasi dua arah dengan Konstituen melalui kunjungan kerja dan bertemu Konstituennya di Daerah Pemilihan (Dapil) masing-masing yang dilakukan secara rutin pada setiap masa Reses”. Reses merupakan kegiatan Pimpinan dan Anggota DPRD untuk menyerap dan menindaklanjuti aspirasi dan pengaduan masyarakat guna memberikan pertanggungjawaban secara moral dan politis kepada masyarakat di daerah pemillihan sebagai perwujudan perwakilan rakyat dalam pemerintahan. Kegiatan penyerapan aspirasi masyarakat tersebut agar dapat sesuai dengan tujuan dan tepat sasaran serta berdaya guna dan berhasil guna, maka pelaksanaan reses perlu mengikuti petunjuk teknis ini.

Tujuan reses adalah menyerap dan menindaklanjuti aspirasi konstituen dan pengaduan masyarakat guna memberikan pertanggungjawaban moral dan politis 
kepada konstituen di Dapil sebagai perwujudan perwakilan rakyat dalam pemerintahan (Sembiring, 2017). Aspirasi masyarakat Kabupaten Bandung yang ditampung dalam reses mencakup Bidang Pemerintahan, Bidang Ekonomi, Bidang Pembangunan dan Bidang Kesejahteraan. Setelah itu anggota DPRD dapat menampung serta melakukan tindak lanjut dari setiap aspirasi tersebut serta pengaduan yang disampaikan oleh masyarakat. Anggota DPRD melakukan pertanggungjawaban moral maupun politis terhadap setiap aspirasi masyarakat yang disampaikan kepada konstituen didaerah pemilihannya.

Tahun sidang DPRD dibagi dalam 3 (tiga) masa persidangan. Masa persidangan meliputi masa sidang dan masa reses, kecuali pada persidangan terakhir dari satu periode keanggotaan DPRD kabupaten/kota, masa reses ditiadakan. Persiapan kegiatan reses dimulai dengan rapat Pimpinan DPRD untuk membahas jadwal pelaksanaan kegiatan reses. Rapat Pimpinan DPRD diikuti oleh Ketua DPRD, Wakil Ketua DPRD I, Wakil Ketua DPRD II, seluruh Ketua Fraksi dan Ketua Daerah Pemilihan bersamaan dengan Sekretaris DPRD. Hal yang menjadi pertimbangan dalam menentukan jadwal kegiatan reses adalah jadwal kegiatan DPRD, kegiatan Pemerintah Daerah dan kegiatan peserta reses yang mengikuti kegiatan reses (Beriansyah \& Mutiarin, 2015). Agar peserta reses dapat menghadiri kegiatan reses, dalam menentukan jadwal kunjungan ke Dapil harus sesuai dengan kegiatan masyarakat di Dapil tersebut.

Sesuai dengan peraturan DPRD Kabupaten Bandung, kegiatan Reses di DPRD Kabupaten Bandung dilaksanakan tiga kali dalam setahun. Dalam kegiatan ini anggota DPRD mengunjungi daerah pemilihannya (Dapil) dimana masyarakat berhadapan langsung dan berbicara terbuka kepada anggota DPRD. Sebagai wakil rakyat, DPRD melaksanakan kegiatan ini guna menyerap langsung aspirasi masyarakat. Dalam Reses ini, anggota DPRD menerima segala keluhan rakyat untuk ditindaklanjuti (Jannus T.H \& Manurung, 2020).

Proses reses DPRD menjadi bagian dari pelaksanaan demokrasi. Sebagaimana disampaikan oleh Sanit (1985:203) bahwa teori demokrasi mengajarkan bahwa anggota masyarakat mengambil bagian atau berpartisipasi dalam proses dan penentuan kebijakan pemerintah. Disini, anggota DPRD dalam 
melaksanakan kewajibannya atas nama rakyat. Baik dalam perumusan serta dalam memutuskan setiap kebijakan yang tentu menyangkut setiap aspek kehidupan dari masyarakat. Setiap wakil rakyat diharapkan mampu menyerap setiap aspirasi masyarakat dengan baik sehingga dapat mengetahui apa saja aspirasi ataupun keinginan yang tengah berkembang di masyarakat.

Masyarakat yang memilih wakil rakyatnya yaitu DPRD tentu mengharapkan kesejahteraan kepada mereka melalui aspirasi yang hendak ditujukan kepada pimpinan DPRD lewat wakil rakyat dari setiap fraksi manapun yang sudah mereka pilih. Tujuan penelitian yang dilakukan adalah mengetahui fungsi reses dari anggota DPRD dalam mengartikulasikan setiap aspirasi dari masyarakat di wilayah Kabupaten Bandung.

DPRD merupakan penyelenggara pemerintah daerah sekaligus badan yang menjembatani antara masyarakat dengan pemerintah. Dalam konteks ini setiap DPRD mempunyai hak dan kewajiban untuk itu dimana yang dimaksud dalam peranannya sebagai anggota DPRD adalah melaksanakan setiap hak yang dimiliki serta kewajibannya sesuai dengan kedudukan dari anggota DPRD tersebut. Anggota DPRD melaksanakan peranannya untuk masyarakat sesuai dengan kewajibannya menampung, menindaklanjuti segala aspek keluhan yang ada di masyarakat. Parlemen yang berada di daerah dalam hal ini DPRD adalah lembaga perwakilan rakyat yang berkedudukan di daerah (Budiardjo, 2008:322). DPRD yang merupakan lembaga perwakilan rakyat merupakan unsur pemerintahan di daerah yang mempunyai tugas membuat peraturan daerah serta menyerap aspirasi masyarakat dan menampung berbagai aspirasi dari masyarakat yang telah memilihnya.

DPRD sebagaimana tercantum dalam Undang-Undang No. 23 Tahun 2014 tentang Pemerintahan Daerah berkedudukan sebagai perwakilan rakyat di daerah dimana merupakan unsur dari penyelenggara di pemerintah daerah. Sebagaimana diketahui bahwa DPRD memiliki 3 (tiga) fungsi yaitu fungsi legislasi, fungsi pengawasan serta fungsi anggaran. Berdasarkan Undang-Undang No. 27 Tahun 2009 tengan MD3 pada pasal 292 ayat 2 dan pasal 343, DPRD tidak hanya melaksanakan fungsi legislasi, pengawasan dan anggaran saja, akan tetapi 
melakukan fungsi representasi juga. Ketiga fungsi yang dimiliki DPRD dijalankan dalam rangka mengemban setiap amanat dari rakyat baik di tingkat provinsi maupun Kabupaten/kota. Fungsi yang pertama yaitu fungsi legislasi. Fungsi legislasi adalah fungsi yang dimiliki oleh DPRD untuk membuat kebijakan melalui peraturan daerah bersama dengan Kepala daerah. Kedua yaitu fungsi pengawasan dimana DPRD memiliki fungsi untuk mengawasi pelaksanaan dari perundangundangan yang telah dibuat, termasuk peraturan daerah serta peraturan kepala daerah dan kebijakan pemerintah daerah lainnya. Fungsi yang ketiga yaitu fungsi anggaran. Fungsi anggaran dari DPRD dilaksanakan bersama dengan pemerintah daerah dalam menyusun serta menetapkan Anggaran Pendapatan dan Belanja Daerah (APBD).

Masa Reses berasal dari bahasa Belanda yaitu recess dimana artinya adalah berlibur. Berdasarkan maknanya tersebut maka reses dilakukan pada liburan sekolah (liburan semester setelah ujian) serta liburan parlemen. Masa reses adalah kegiatan untuk berhenti dari segala kegiatan DPRD di tengah masa tugasnya. DPR maupun DPRD melakukan reses sebagaimana yang dilakukan di negara Belanda dimana anggota parlemen yang berkedudukan sebagai anggota volksraad (DPR) maupun regentschapsraad (DPRD) yang berkedudukan di kabupaten/kota, yang saat itu mengikuti liburan. Pelaksanaan masa reses tersebut sekali setahun selama kurun waktu tiga bulan (Prihatmoko 2006:4). Namun reses dalam konteks politik memiliki makna kunjungan yang dilakukan DPR/DPRD ke daerah pemilihannya untuk menyerap serta menampung setiap aspirasi rakyat.

Bagi semua anggota DPRD wajib mengunjungi setiap daerah pemilihannya dimana bertujuan untuk dapat menyerap aspirasi masyarakat yang telah memilihnya. Setiap anggota DPRD setelah melaksanakan kegiatan pada masa reses kemudian membuat laporan pelaksanaan kegiatan tersebut lalu disampaikan dalam rapat paripurna (Marijan 2010:53). Zuhri (2012:4) memberikan penjelasan bahwa reses sendiri adalah komunikasi dua arah antara legislatif dengan konstituen melalui kunjungan kerja secara berkala. Zuhri menjelaskan lebih lanjut bahwa kegiatan reses terdiri dari 4 (empat) tahap yaitu:

1) Rapat Badan Musyawarah tentang jadwal pelaksanaan dan lokasi reses. 
2) Penjelasan pelaksanaan reses oleh pimpinan dan Sekretariat DPRD.

3) Masa Tugas reses.

4) Rapat Laporan reses.

Masa Reses adalah bagian dari persidangan. Masa reses digunakan anggota DPRD dengan cara perseorangan maupun berkelompok untuk meninjau hasil daerahnya sebagai upaya penyerapan aspirasi dari rakyat. Reses merupakan kewajiban yang harus dilaksanakan oleh anggota DPRD dalam upaya untuk meningkatkan kualitas serta produktivitas kinerja anggota guna mewujudkan keadilan dan kesejahteraan rakyat (Maharani \& Kusuma, 2017).

Dalam pelaksanaannya, penyerapan aspirasi yang diberikan oleh masyarakat dilaksanakan oleh pemerintah maupun DPRD melalui kegiatan reses. Penyerapan aspirasi masyarakat yang dilaksanakan oleh pemerintah melalui pelaksanaan musyawarah perencanaan pembangunan sedangkan penyerapan aspirasi oleh DPRD dilaksanakan dalam dua tahap yaitu secara langsung maupun tidak langsung. Setiap aspirasi yang disampaikan oleh masyarakat menjadi sebuah harapan bagi kesejahteraan mereka dan adanya tujuan yang hendak dicapai di masa depan. Aspirasi masyarakat berupa cita-cita, keinginan, hasrat serta berbagai keinginan dari masyarakat yang begitu kuat dalam mencapai sesuatu, diantaranya adalah mencapai keberhasilan dari tujuan yang diinginkan oleh masyarakat tersebut (Lolowang, 2021).

Menurut Archon Fung terdapat tiga metode yang dilaksanakan untuk dapat memahami setiap aspirasi yang diinginkan oleh rakyat sebagai berikut:

1. Luas lingkup partisipasi akan menentukan siapa saja yang berhak menyalurkan aspirasinya untuk mempengaruhi sebuah kebijakan. Terdapat lima model dasar yang membedakan luasnya ruang pastisipasi bagi penyalur aspirasi rakyat; yang pertama, self selected, yaitu mekanisme yang sepenuhnya membebaskan masyarakat untuk menyalurkan aspirasinya atau tidak. Kedua, rekurtmen terseleksi, yaitu hanya orang - orang tertentu yang memenuhi persayaratan saja yang memiliki hak untuk menyalurkan aspirasinya dalam proses pembuatan kebijakan. Ketiga, random selection yang juga sering dikenal dengan teknik polling, yaitu penyerapan aspirasi masyarakat dengan memilih secara acak beberapa individu yang dianggap mewakili masing masing komunitas. Keempat, lay stakeholders, yaitu proses penyerapan aspirasi yang melibatkan beberapa warga negara yang secara sukarela 
mau bekerja tanpa dibayar. Sekelompok warga diberi kepercayaan untuk memikirkan atau menangani suatu kebijakan tertentu. Kita sudah mengenal prinsip penyaluran aspirasi semacam ini, misalnya melalui Komite Sekolah dan Dewan Pendidikan. Kelima, Professional Stakeholders, yaitu pembuatan kebijakan publik yang melibatkan tenaga - tenaga professional yang digaji atau diberi honorarium. Asumsinya, tenaga - tenaga professional ini memiliki kapasitas menemukan solusi terbaik untuk mengatasi permasalahan yang dihadapi oleh masyarakat.

2. Melihat jenis komunikasi yang terjadi antara pemerintah dengan warganya, apakah satu arah atau timbal balik. Model komunikasi timbal balik memberikan ruang yang lebih luas bagi proses penyerapan aspirasi yang lebih berkualitas.

3. Melihat relevansi antara perkembangan aspirasi dengan substansi kebijakan. Semakin relevan produk kebijakan yang menghasilkan dengan persoalan rill yang berkembang di masyarakat, maka proses penyerapan aspirasi yang terjadi di masyarakat bisa dikatakan semakin berkualitas(Lolowang, 2021).

Tiga metode di atas, digunakan untuk melihat sejauh mana aspirasi dari masyarakat. Apa saja komunikasi yang digunakan antara pemerintah dan masyarakat serta melihat relevansi dari aspirasi masyarakat terhadap substansi kebijakan yang dibuat oleh pemerintah.

Anggota DPRD dalam menghasilkan reses yang lebih baik lagi perlu mengidentifikasi berbagai permasalahan yang ada pada dapilnya. Lebih baik lagi merancang strategi guna memperjuangkan aspirasi tersebut. Baik itu melalui kelembagaan maupun komunikasi yang lebih baik lagi dengan berbagai instansi, eksekutif maupun SKPD selaku pihak yang berwenang membuat keputusan publik. Selain itu, dalam melakukan kegiatan reses perlu adanya buku panduan reses. Dengan adanya buku panduan reses tersebut, maka kegiatan reses akan lebih sistematis dan progresif (Hidayatullah \& Pribadi, 2016).

Artikulasi kepentingan menurut Sastroatmojo yaitu "suatu proses yang mengolah aspirasi masyarakat yang bercorak ragam yang disaring dan dirumuskan dalam bentuk rumusan yang teratur. Dengan demikian, aspirasi yang beraneka ragam dapat dipahami untuk selanjutnya dicerminkan dalam kebijaksanaan" (Kristiani, Sonya, \& Lapalu, 2018). 


\section{PEMBAHASAN}

Reses menjadi salah satu kewajiban yang harus dilaksanakan oleh anggota DPRD sebagaimana telah tercantum dalam Undang-Undang MD3. Reses sendiri dilaksanakan sebagai upaya menampung setiap aspirasi dari masyarakat. Pelaksanaan reses dilaksanakan secara berkala di daerah pemilihan dari masingmasing anggota DPRD. Hasil dari pelaksanaan reses diajukan pada pembahasan sidang paripurna DPRD. Setiap aspirasi yang ditampung dalam masa reses dilaksanakan guna meningkatkan kualitas dari kinerja anggota DPRD dalam mewujudkan kesejahteraan rakyat, keadilan sosial, serta mewujudkan peran dari DPRD mengembangan check and balances antara DPRD tentunya dengan pemerintah daerah. Reses yang dilaksanakan oleh setiap anggota DPRD bertujuan untuk dapat menyerap serta mampu menindaklanjuti berbagai aspirasi yang disampaikan oleh konstituen. Selain itu, proses reses dilaksanakan untuk mendengar pengaduan dari masyarakat sebagai wujud dari pertanggungjawaban baik moral maupun politis terhadap konstituen pada daerah pemilihannya. Hal tersebut menjadi wujud dari perwakilan rakyat terutama dalam pemerintahan.

Masa reses anggota DPRD menurut Wasistiono dibagi menjadi empat tahap yang meliputi:

a. Persiapan Persiapan reses harus sudah disepakati mengenai hal-hal yang berhubungan dengan waktu, tempat, kelompok sasaran, anggaran yang dibutuhkan, data dasar yang menjadi lokasi reses.

b. Pelaksanaan. Pelaksanaan reses harus mengorganisasikan hal-hal yang sedang direncanakan pada tahap persiapan. Dilakukan secara tatap muka baik dengan kelompok kecil maupun kelompok besar.

c. Pelaporan. Pelaporan reses berarti laporan sebagai pelaksanaan komunikasi secara tertulis dan lisan, sedangkan secara khusus dalam konteks administrasi adalah pertanggungjawaban pelaksanaan tugas dan fungsi setiap satuan organisasi. Laporan ini memilikiperan penting dalam komunikasi administrasi, pertanggngjawaban dan pengawasan serta pengendalian, penyampaian informasi, beban pengambilan keputusan, alat membina kerjasama, dan alat pengembangan wawasan. 
d. Tindak lanjut hasil reses. Diharapkan DPRD menindaklanjuti laporan anggota DPRD tentang hasil reses dengan mendistribusikan kepada alat kelengkapan DPRD untuk dibawa dalam agenda rapat pada masing-masing sesuai dengan persoalanya. Lain dapat dilakukan melalui media masa, partai politik, serta Pemerintah Daerah.

(Wasistiono,2009:197)

Anggota DPRD Kabupaten Bandung telah melaksanakan reses pada masa sidang II Tahun 2021. Masa reses yang dilaksanakan anggota DPRD Kabupaten Bandung merupakan masa dimana setiap anggota DPRD melakukan kegiatan di luar masa sidang. Pelaksanaan masa reses tersebut dilaksanakan di luar gedung DPRD Kabupaten Bandung. Setiap anggota dewan berkesempatan untuk bertemu dan menjumpai konstituen di daerah pemilihannya (Dapil) masing-masing. Kegiatan reses ini dilakukan guna mendengarkan secara langsung aspirasi yang ada di masyarakat. Sehingga nantinya bisa diambil sebuah keputusan yang terbaik. Termasuk usulan pembangunan. Pelaksanaan reses ini dilaksanakan dengan dengan pengawasan menjalankan protokol kesehatan Covid-19.

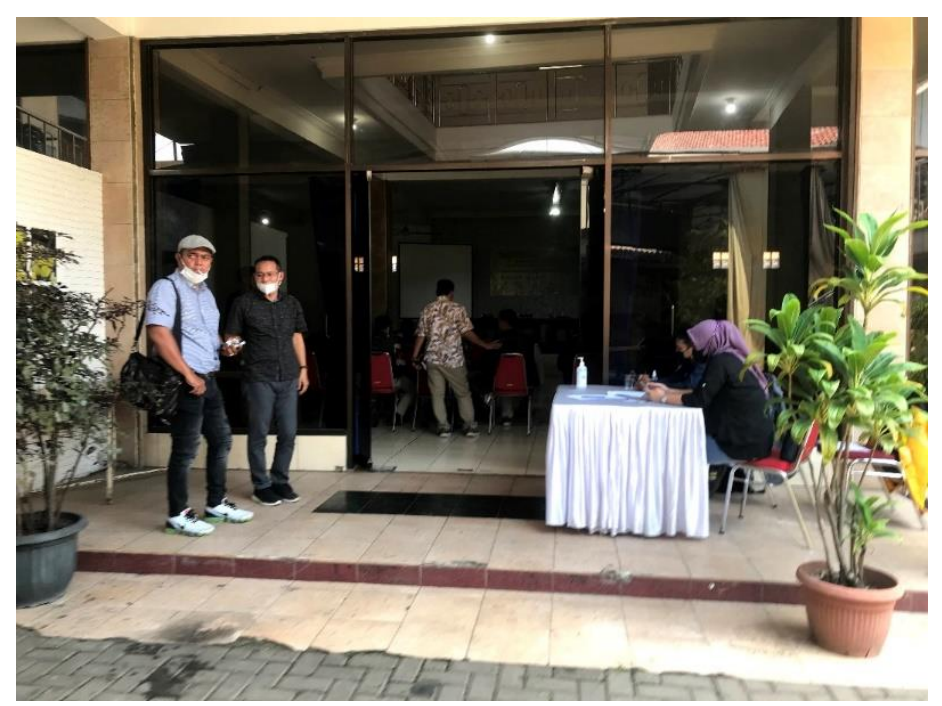

Pelaksanaan kegiatan reses anggota dewan disampaikan dalam Peraturan Bupati Bandung Nomor 42 Tahun 2020 Tentang Petunjuk Teknis Pelaksanaan Kegiatan Reses Pimpinan Dan Anggota DPRD Kabupaten Bandung. Peraturan Bupati Bandung tersebut disebutkan bahwa mekanisme Masa Reses mengikuti 
masa persidangan, yang dilakukan sebanyak 3 (tiga) kali dalam setahun atau 14 (empat belas) kali Reses dalam periode 5 (lima) tahun masa jabatan DPRD.

Perhitungan 1 (satu) kali kegiatan Reses dilaksanakan bersama 375 (tiga ratus tujuh puluh lima) konstituen dengan rentang waktu paling lama 6 (enam) hari. Sekretaris DPRD mengumumkan agenda Reses setiap Anggota DPRD paling lambat 3 (tiga) hari sebelum masa Reses dimulai melalui saluran yang mudah diakses. Reses dapat dilakukan secara perseorangan atau kelompok yang difasilitasi oleh TA. Masa Reses Anggota DPRD secara perseorangan atau kelompok dilaksanakan dengan memperhatikan:

a. waktu Reses Anggota DPRD di wilayah pemilihan yang sama;

b. rencana kerja Pemerintah Daerah;

c. hasil pengawasan DPRD selama masa sidang; dan

d. kebutuhan konsultasi publik dalam pembentukan peraturan Daerah.

Biaya penunjang lain yang dianggarkan adalah biaya perjalanan dinas dalam Daerah bagi Pimpinan dan Anggota DPRD untuk jangka waktu paling lama 6 (enam) hari, dalam rangka persiapan dan pelaksanaan kegiatan Reses.

Anggota DPRD wajib melaporkan hasil pelaksanaan Reses kepada Pimpinan DPRD, paling sedikit memuat:

a. waktu dan tempat kegiatan Reses;

b. tanggapan, aspirasi dan pengaduan dari masyarakat; dan

c. dokumentasi peserta dan kegiatan pendukung.

Anggota DPRD yang tidak menyampaikan laporan sebagaimana dimaksud pada ayat (1), tidak dapat melaksanakan Reses berikutnya. Masa reses DPRD idealnya mampu digunakan secara efektif untuk menggali aspirasi masyarakat di daerah dan memperkuat fungsi dewan khususnya dalam menjalankan fungsi legislasi dan budgeting. Melalui masa reses inilah keinginan masyarakat semestinya mampu ditangkap dan dijadikan pedoman perjuangan anggota DPRD. Hasil-hasil reses semestinya dapat dijadikan referensi bagi dewan untuk menjalankan fungsi legislasi dan budgeting berdasar kebutuhan masyarakat daerah.

Anggota DPRD Kabupaten Bandung sebagai wakil rakyat, memiliki kewajiban melakukan pertanggungjawaban kepada masyarakat, baik secara politik, 
yuridis, maupun moral. Kegiatan penyerapan aspirasi masyarakat melalui reses anggota DPRD menjadi salah satu sarana penghubung antara lembaga pemerintahan disatu pihak dengan masyarakat dalam wilayah Kabupaten Bandung. (S.A, Hananto, \& Hardjanto, 2019). Dalam mengolah aspirasi masyarakat yang bercorak ragam yang disaring dan dirumuskan dalam bentuk rumusan yang teratur sehingga aspirasi masyarakat yang beraneka ragam dapat dipahami untuk selanjutnya dicerminkan dalam suatu kebijaksanaan yaitu penyerapan aspirasi masyarakat yang dilakukan oleh DPRD melalui reses.

Masa reses DPRD Kabupaten Bandung pada sidang ke-II berlangsung antara tanggal 22 sd 31 Maret 2021. Dikarenakan situasi pandemi Covid-19, maka pelaksanaan reses harus memenuhi protokol kesehatan secara ketat. Meskipun demikian, hal ini tidak menyurutkan semangat masyarakat mengikuti kegiatan reses. Sebelum masuk tempat reses setiap undangan diwajibkan memakai masker, dan diwajibkan untuk diperiksa suhu tubuh dari setiap tamu yang diundang, mereka tidak ada yang memiliki suhu tubuh yang tinggi sehingga diperbolehkan mengikuti acara reses anggota DPRD Kabupaten Bandung. Tampak sejumlah masyarakat antusias dalam menyampaikan aspirasi untuk kemajuan daerah.

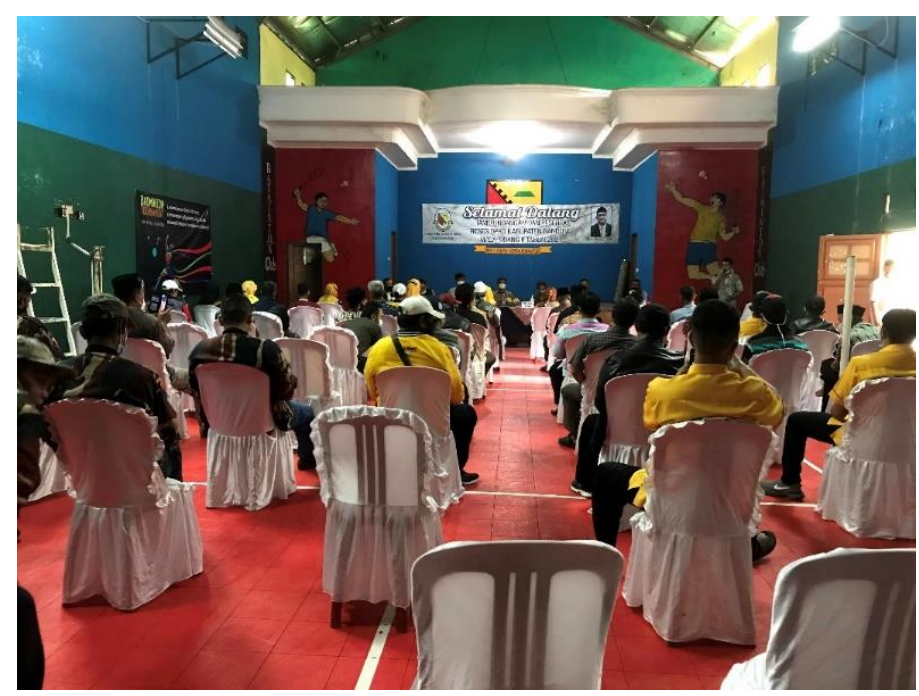

Dikarenakan belum selesainya proses pelantikan kepala daerah Kabupaten Bandung, maka program-program pembangunan terhambat untuk didanai, termasuk dana desa yang belum bisa turun. Aspirasi masyarakat pada umumnya sangat menginginkan perbaikan-perbaikan infrastruktur. Semua daerah yang 
kunjungi saat reses, berharap agar anggaran pembangunan bisa segera berjalan termasuk aspirasi dari semua anggota dewan agar bisa membantu juga masyarakat. DPRD Kabupaten Bandung seharusnya berupaya agar aspirasi masyarakat yang dijaring melalui program reses tersebut dapat terakomodir dalam postur APBD. Sehingga hal ini tidak menimbulkan perdebatan antara DPRD dan Pemerintah Daerah saat proses pembahasan anggaran. Argumen perdebatan tidak keluar dari hal-hal yang bersifat prinsipil. Bahkan menurut Lule "DPRD baik secara pribadi maupun kelembagaan selalu mengingatkan kepada Tim Anggaran Pemerintah Daerah (TAPD) agar tidak melakukan pemangkasan terhadap anggaran yang dianggap memberikan jaminan kesejahteraan terhadap masyarakat terutama anggaran pemberdayaan masyarakat" (Alwadud Lule, 2017).

Selain pembangunan fisik, hal-hal non fisik juga sangat penting. Pembangunan non fisik menjadi salah satu upaya membangkitkan masyarakat dalam proses pemulihan sektor sosial maupun ekonomi di masa pandemi covid-19. Fokus dari reses anggota DPRD Kabupaten Bandung yaitu ingin mendorong masyarakat untuk menjalankan usaha-usaha yang sifatnya mandiri, seperti pembentukan koperasi, pemberian modal usaha dan sebagainya. Upaya anggota DPRD dalam menjaring aspirasi masyarakat pada saat turun langsung ke daerah pemilihannya, diharapkan pada saat sidang mampu merealisasikan aspirasi tersebut.

Pelaksanaan fungsi artikulasi kepentingan menunjukkan bahwa terdapat berbagai macam aspirasi masyarakat yaitu terdiri dari 21 usulan/input dari masyarakat dengan mayoritas usulan yaitu permasalahan infrastruktur jalan yang diusulkan untuk diperbaiki serta usulan lain yang disampaikan masyarakat seperti mengusulkan program ramah anak, kelangkaan gas elpigi $3 \mathrm{~kg}$, pembuatan perda tentang peredaran obat-obat terlarang, memohon bantuan kartu Indonesia Pintar (KIP), mengusulkan pembuatan polisi tidur, penambahan gedung sekolah serta mengusulkan pembagian pohon produktif untuk menambah penghasilan masyarakat.

Selanjutnya diharapkan pihak Pemerintah Daerah Kabupaten Bandung dapat menyamakan program prioritas bersama DPRD Kabupaten Bandung 
berdasarkan permasalahan yang ada di tengah masyarakat guna penyusunan peraturan daerah, penyusunan anggaran serta melaksanakan pengawasan yang dapat mengakomodir kepentingan masyarakat Kabupaten Bandung. Sealin itu, masyarakat Kabupaten Bandung diharapkan dapat berperan aktif menyampaikan tuntutan atau saran terhadap setiap masalah yang ada di lingkungan masyarakat kepada anggota DPRD Kabupaten Bandung agar dapat melaksanakan setiap tugas dan tanggung jawab sebagai wakil rakyat dengan memperjuangkan aspirasi masyarakat sehingga tindak lanjut dari berbagai aspirasi hasilnya dapat diketahui dan diukur oleh masyarakat guna pembangunan di Kabupaten Bandung.

\section{KESIMPULAN}

DPRD Kabupaten Bandung telah melaksanakan amanat Reses sesuai Pasal 108 huruf (i) dan 161 huruf (i) Undang-Undang Nomor 23 tahun 2014 tentang Pemerintahan Daerah. Pelaksanaan reses ini telah sesuai dengan Peraturan Bupati Bandung Nomor 42 Tahun 2020 tentang Petunjuk Teknis Pelaksanaan Kegiatan Reses Pimpinan dan Anggota DPRD Kabupaten Bandung. Pimpinan dan anggota DPRD Kabupaten Bandung telah melakukan kunjungan berkala atau reses untuk mengunjungi konstituenya di daerah pemilihannya masing-masing setiap 3 kali dalam satu tahun sesuai keputusan Badan Musyawarah. Antusiasme masyarakat terhadap reses pimpinan dan anggota DPRD Kabupaten Bandung cukup baik. Hal tersebut terbukti dengan banyaknya masyarakat yang berbondong-bondong mengikut kegiatan reses tersebut dan ikut menyampaikan aspirasi kepada anggota DPRD yang mewakili mereka. Aspirasi masyarakat tersebut kemudian dicatat oleh anggota DPRD yang melakukan reses untuk kemudian dilaporkan kepada fraksi untuk disampaikan pada saat sidang paripurna. 


\section{DAFTAR PUSTAKA}

Agus Dwiyanto. (2003). Reformasi Tata Pemerintahan dan Otonomi Daerah. Yogyakarta: Pusat Studi Kependudukan dan Kebijakan UGM.

Budiardjo, Miriam (2008). Dasar-dasar Ilmu Politik. Jakarta: PT. Gramedia.

Alwadud Lule, I. L. (2017). DINAMIKA INTERAKSI LEGISLATIF DAN EKSEKUTIFDI PULAU MOROTAI (Mengurai Konfigurasi Politik dan Penjelasan Alternatif). 1-20.

Beriansyah, A., \& Mutiarin, D. (2015). Analisis Hasil Reses DPRD dalam Penyusunan Dan Penetapan APBD Kabupaten Ogan Komering Ulu Selatan Tahun Anggaran 2014. Journal of Governance and Public Policy, 2(2). https://doi.org/10.18196/jgpp.2015.0038

Hendriyanto, R. (2020). Analisis Akuntabilitas Politik Reses, Studi Tentang Kegiatan Reses Anggota DPRD Provinsi Jawa Tengah. 15.

Hidayatullah, H., \& Pribadi, U. (2016). Analisis Jaring Aspirasi Melaui Reses Dewan Perwakilan Rakyat Daerah Lombok Timur Tahun 2015. Journal of Governance and Public Policy, 3(2), 339-367. https://doi.org/10.18196/jgpp.2016.0062

Jannus T.H, S., \& Manurung, S. (2020). PERANAN ANGGOTA DPRD SUMATERA UTARA FRAKSI PERSATUAN KEADILAN BANGSA DALAM MENGUPAYAKAN ASPIRASI MASYARAKAT. Jurnal Governance Opinion, 5(1), 30-40.

Kristiani, M. N., Sonya, E., \& Lapalu, U. (2018). PERAN PARTAI POLITIK DALAM AKOMODASI KEPENTINGAN DI FRAKSI DPRD KOTA PALANGKA RAYA Margaretha Novi Kristiani, Ester Sonya Ulfaritha Lapalu. $V(2), 85-91$.

Lolowang, P. J. (2021). Peran Anggota Dprd Fraksi Pdi Perjuangan Dalam Menyalurkan Aspirasi Masyarakat Kabupaten Minahasa. Jurnal Politico, 10(4).

Maharani, A. E. P., \& Kusuma, Y. R. (2017). IMPLEMENTASI UNDANGUNDANG NOMOR 23 TAHUN 2014 TENTANG PEMERINTAHAN DAERAH TERHADAP PROSES MASA RESES ANGGOTA DPRD KABUPATEN SUKOHARJO DALAM PENJARINGAN ASPIRASI MASYARAKAT UNTUK MEWUJUDKAN PRINSIP KEDAULATAN RAKYAT. Res Publika (Jurnal Hukum Kebijakan Publik), 1(1), 118-133.

Rizka Azzahri, Seno Andri, \& Adianto. (2021). Efektivitas Penggunaan Dana Reses Anggota Dewan Perwakilan Rakyat Daerah (DPRD) Kota Pekanbaru Dalam 
Menyerap Aspirasi Masyarakat. Jurnal Niara, 14(1), 266-275. https://doi.org/10.31849/niara.v14i1.5133

S.A, T. D., Hananto, U. D., \& Hardjanto, U. S. (2019). PELAKSANAAN TUGAS ANGGOTA DPRD DALAM PENYERAPAN ASPIRASI MASYARAKAT BERDASARKAN UNDANG-UNDANG NOMOR 23 TAHUN 2014 TENTANG PEMERINTAHAN DAERAH. Diponegoro Law Journal, 8(4), 2797-2809.

Sembiring, E. Z. (2017). ANALISIS RESPON MASYARAKAT TERHADAP PELAKSANAAN RESES DPRD KOTA MEDAN TAHUN 2016 DALAM PENETAPAN KEBIJAKAN PUBLIK ( Studi pada Masayarakat Kecamatan Medan Helvetia Kota Medan ) PROGRAM STUDI MAGISTER ADMINISTRASI PUBLIK PROGRAM PASCASARJANA UNIVERSITAS ME.

Zuhri. (2012). Buku Panduan Reses. Pangkal Pinang.

\section{PERATURAN PERUNDANG-UNDANGAN}

Undang-Undang Dasar Negara Republik Indonesia 1945. Undang-Undang Nomor 23 Tahun 2014 Tentang Pemerintahan Daerah.

Undang-Undang Nomor 27 Tahun 2009 tentang Majelis Permusyawaratan Rakyat, Dewan Perwakilan Rakyat, Dewan Perwakilan Daerah, dan Dewan Perwakilan Rakyat Daerah

Peraturan Pemerintah Nomor 16 Tahun 2010 tentang Pedoman Penyusunan Peraturan Dewan Perwakilan Rakyat Daerah Tentang Tata Tertib Dewan Perwakilan Rakyat Daerah.

Peraturan Bupati Bandung Nomor 42 Tahun 2020 Tentang Petunjuk Teknis Pelaksanaan Kegiatan Reses Pimpinan Dan Anggota DPRD Kabupaten Bandung. 